\title{
The Sequencing of hpmB Gene in Proteus mirabilis Among UTIs Patients
}

\author{
Anwar M. Lazm¹, Mohammed S. Jebur ${ }^{2}$, Hussein O.M. Al-Dahmoshi* and Noor S. \\ Al-khafaji ${ }^{3}$ \\ ${ }^{1}$ Department of Biology, Al-Farabi University College, Baghdad, Iraq. ${ }^{2}$ College of Health and Medical Technology, \\ Middle Technical University, Baghdad, Iraq. ${ }^{3}$ Biology Department, College of Science, University of Babylon, \\ Babylon, Iraq.
}

\begin{abstract}
The present study was carried out during February to May 2018 in Baghdad hospitals. A sample of urine has been collected from fifty patients with an infection in their urinary tract (UTIs) of both sexes and different ages. Bacteriological investigation of urine samples from UTIs patients is made to isolate and diagnose Proteus mirabilis bacterium. In addition, the study detects the phenotypic and genetic characteristic of Proteus mirabilis $\alpha$-hemolysin activity. Moreover, for the study to prove its hypothesis, a molecular detection has been carried out utilizing specific primer to $h p m B$ gene which encodes $\alpha$-Hemolysin as a factor of virulence of Proteus mirabilis through the use of PCR. The results show that $7(\% 100)$ of isolates are positive for $h p m B$ at $422 \mathrm{bp}$. Two isolates of $P$. mirabilis are sequenced as hpmB genes. The ratio of identity of the hpmB genes with the CP017085.1 and CP020052.1 stains at NCBI global databases copmrised $100 \%$, $99 \%$ respectively.
\end{abstract}

Keywords: P. mirabilis, virulence factors gene $h p m B$, Sequencing.

*Correspondence: dahmoshi83@gmail.com; +9647807771411

(Received: 29 October 2018; accepted: 15 December 2018)

Citation: Anwar M. Lazm, Mohammed S. Jebur, Hussein O. M. Al-Dahmoshi and Noor S. Al-khafaji, The Sequencing of hpmB Gene in Proteus mirabilis Among UTIs Patients, J Pure Appl Microbiol., 2019; Vol. 13(1):447-453 doi: 10.22207/JPAM.13.1.49

C The Author(s) 2019. Open Access. This article is distributed under the terms of the Creative Commons Attribution 4.0 International License which permits unrestricted use, sharing, distribution, and reproduction in any medium, provided you give appropriate credit to the original author(s) and the source, provide a link to the Creative Commons license, and indicate if changes were made. 


\section{INTRODUCTION}

Proteus mirabilis refers to a Gramnegative bacterium ${ }^{1}$. Its harmful virulence factors can be recognized by $P$. mirabilis that is able to access and settle the host urinary tract. These include toxins like hemolysin and its function of pore formation, biofilm formation and regulation of pathogenesis ${ }^{2}$. Proteus mirabilis has numerous virulence factors that may inflict UTIs. These factors have an important role in causing an infection in varying spots of the urinary tract ${ }^{3}$. Alpha $(\alpha)$ hemolysin hpmA is created by $P$. mirabilis that leads to an injury in kidney tissues. This $\alpha$-hemolysin belongs to the cell, independent of calcium, pores-former which is encoded by two genes, hpmA and hpmB, that control the hpmB (63kDa) proteins ${ }^{3}$. hpmA $\alpha$-hemolysin accountable for destructive and triggering the tissue when its $\mathrm{N}$-terminal peptide is slashed. So, the result can activate hpmA and hpmB that is responsible for hpmA activation and transport ${ }^{4}$. The present study aims to characterize the $h p m B$ among $P$. mirabilis isolated from UTIs patients.

\section{MATERIALS AND METHODS}

Patients with urinary tract infection are from Baghdad Teaching Hospital during the period from September to October 2018. Midstream urine samples are collected and controlled in sterilized wide-container from one hundred urinary tract infection patients. The extraction of the Proteus mirabilis DNA from bacterial cells is carries out by using Genomic DNA Mini kit which supplemented by the manufacturing company (Promega, US). DNA electrophoresis in agarose gel is performed according to Ouda, $2014^{5}$.

Thermic cycles program for amplifying the DNA

Specific primers are used for detecting the Proteus mirabilis virulence gene encodes of $\beta$-hemolysin sequence according to Cestari et al., $2013^{6}$. These primers are provided by Promega Company (USA) and prepared according to the information of the supplying company, which is listed below:

\section{DNA Sequencing of $h p m B$ gene}

The process of sequencing through PCR-sequences included two. This is performed according to Macrogen company/Korea sending. The nucleotide replacement is decided by comber. The data that obtained are from gene bank which is available at NCBI https://www.ncbi. nlm.nih.gov.

\section{RESULTS AND DISCUSSION}

The technique used to investigate the genes responsibility for the virulence factor in P. mirablis is Single Polymerase Chain Reaction Technique. This has been conducted through using segments of the DNA with restricted number of nucleotides (oligonucleotide). Their action is to be primers specialized for virulence genes in $P$. mirablis., hpmB is also included and it is responsible for producing hemolycin $P$. mirabilis $\beta$-hemolysin that is different from other Proteus spp. It is organized by two genes, (hpmA and $\mathrm{hpmB}$ ) that encodes the hpmA and hpmB proteins respectively ${ }^{7,8}$.

The present study shows that hpmB gene is present in all 7 isolates at rate $(100 \%)$ from urine samples of RA patients as shown in fig (1). The results contest the result which is verified by Al-Jumaily and Zgaer. In their study, it is declared that the frequency of this gene in P. mirablis isolates is \%100; that is isolated from patients suffering from urinary tract infections ${ }^{9}$. While Cestari et al., 2013 find the ratio of this gene in bacterial isolates comprising $96.24 \%$ existing amplification for the hpmA and hpmB genes by PCR. ${ }^{6}$. The $\alpha$-hemolycin toxin acts as a destroyer to the leukocyte membrane through creating small holes in the leukocyte membrane and epithelial cell. So, its presence is a vital factor in supplying the bacteria with iron and because of having the cytotoxic effects, this could lead to the destruction of the host kidney tissue ${ }^{10}$. Isolates with hpmA gene in them is in compatibility with the characterization presented by Uphoff and Welch (1990) who state the necessity of cleaving the $\mathrm{N}$-terminal peptide of the hpmA by hpmB for the purpose of activating and transporting the hemolytic hpmA protein out of the cell ${ }^{8}$. This standard indicates that hpmA is a factor in the pathogenesis of $P$. mirabilis samples isolated from human urine ${ }^{10}$. Among the other results are those reported by Swihart and Welch,1990 refering that all $P$. mirabilis strains as having hpmA but HlyA is not detected in $P$. mirabilis isolates and is found only in 2 of the 24 P. vulgaris strains examined. Since $P$. mirabilis composes most $(97 \%)$ of the Proteus urinary tract isolates, this suggests that hpmA is the predominant Proteus hemolysin and 
might play a role in extra intestinal infections caused by Proteus spp ${ }^{11}$. These positive isolates with hpmB gene are also checked to confirm their ability to produce hemolysin on blood agar and it has been found that all the isolates $(100 \%)$ have the ability to produce hemolysin. These results agree with the results of Sosa et al. (2006) and AL-Jumaa et al. (2011), who demonstrate that all isolates $(100 \%)$ of Proteus bacterium which are isolated from different clinical sources exhibit hemolysis on blood agar plates, but Mishara et al. (2001) find that (85.14\%) of Proteus isolates produce $\alpha$-hemolysis while other isolates produce $\beta$-hemolysis on blood agar plate ${ }^{12,13,14}$. The results of the study demonstrate that the detection of hpmB gene by PCR is sensitive enough to be used for discovering these virulence factors produced by $P$. mirabilis. The PCR technique is shown to be precise, fast, cheap and more accurate therefore this suggests that hpmB could be used as a diagnostic tool for $P$. mirablis bacterium.

\section{DNA sequencing analysis}

Analyzing DNA sequence of $h p m B$ gene

Three isolates were sequenced by Macrogen/Korea. The nucleotide switch is firmed by comber. The data are obtained from gene bank available at NCBI (https://www.ncbi.nlm.nih.gov). The results of gene sequence analysis hpmB show that there are two polymorphism in 2 isolates of the gene hpmB as shown in fig (2) and table (1). In the isolation of $P$. mirabilis (MF993448) Thymine nucleotide substitutions to Adenine is found at locus 2389107 and Cytosine has substitutions to Thymine at locus 2389062 . Finally, the results show nonsense polymorphism as predict. Also, the results show silent variation and this type of variation doesn't change the sequence of amino acid in the protein and doesn't alter protein function as shown in table $(1)^{15}$. Samples (MF993446) show $100 \%$ identity for hpmB in comparison to the same genes of the CP017085.1. While samples, (MF993448) show $99 \%$ identity for hpmB in comparison to the same genes of the : CP020052.1 strain.

It is noticed, through the process of sequencing of the a-hemolysin at $P$. mirabilis, that it consists of two genes hpmA and hpmB'. P. mirabilis hemolysin hpmA investigation and description is necessary to clarify its significance as a virulence factor. Furthermore, it might have a possible association with other elements that are produced by $P$. mirabilis. These altogether could contribute to cytotoxicity in the UTIs of humans ${ }^{7}$. Mordi and Momoh.(2009) find that a change in the amino acid or replacement with other amino acid may lead to a change in the nature of protein or output and thus lead to the emergence of strains resistant or sensitive to antibiotics[16]. The hpmA and hpmB genes are sequenced from local isolated samples presented $98 \%$ identity for $\mathrm{hpmA}$ and hpmB compared to the same genes of the HI4320 (wild strain) (NCBI GenBank Number NC_010554.1). When the samples of the study are compared with each other $100 \%$ identity is found among these genes ${ }^{17}$. The results of the study display that the amino acid remained the same and that indicates variation from the silent type. In contrast, there is a study conducted on hpmB gene like Strauss et al., (1997) find that mutations enhance the function of hpmB (increase in hemolytic activity). This increasing in hemolytic activity could be a result of hpmB activating and secreting more hpmA ${ }^{18}$. Genotyping works to establish the relationship between bacteria strain on the basis of their genetic content uses. Many genotyping methods become important in the field of genealogy, classification of bacteria, identification of sources, method of infection and the differentiation of strain of high virulent bacteria to prevent their spread and elimination ${ }^{19}$.

Table 1. Primer sequence of $h p m \mathrm{~B}$ gene and PCR condition

\begin{tabular}{ccccc}
\hline Genes & Sequence (5' to 3') & PCR condition & Size (bp) & References \\
\hline hpmB & F:CAGTGGATTAAGCGCAAATG & $95^{\circ} \mathrm{C} 5 \mathrm{~min} 1 \mathrm{x}$ & 422 & \\
& & $95^{\circ} \mathrm{C} 30 \mathrm{sec}$ & & \\
& & $62^{\circ} \mathrm{C} 30 \mathrm{sec} 30 \mathrm{x}$ & (Cestari \\
& R:CCTTCAATACGTTCAACAAACC & $72^{\circ} \mathrm{C} 20 \mathrm{sec}$ & et al., 2013) \\
& & $72^{\circ} \mathrm{C} 5 \mathrm{~min} 1 \mathrm{x}$ & &
\end{tabular}


Table 2. Identity of $h p m B$ gene sequence in

\begin{tabular}{llllll}
\hline Range of nucleotide & Sequence ID & Score & Expect & Identities & Source \\
\hline 3196590 to 3196919 & CP017085.1 & 610 & 0 & $100 \%$ & Proteus mirabilis HPMB \\
2389008 to 2389362 & CP020052.1 & 645 & 0 & $99 \%$ & Proteus mirabilis HPMB \\
\hline
\end{tabular}

Table 3. Polymorphism of $h p m B$ gene sequence

\begin{tabular}{llllll}
\hline Sample & $\begin{array}{l}\text { Type of } \\
\text { substitution }\end{array}$ & $\begin{array}{l}\text { Location } \\
\text { change }\end{array}$ & $\begin{array}{l}\text { Nucleotide } \\
\text { change }\end{array}$ & Amino acid & Effect \\
\hline 1 & & & None & Silent \\
2 & $\begin{array}{l}\text { Transversion } \\
\text { Transition }\end{array}$ & 2389107 & $\begin{array}{l}\text { ACT }>\text { ACA } \\
\text { TTC }>\text { TTT }\end{array}$ & $\begin{array}{l}\text { Threonine }>\text { Threonine } \\
\text { Phenylalanine }>\text { Phenylalanine }\end{array}$ & \begin{tabular}{l} 
Silent \\
\hline
\end{tabular} \\
\hline
\end{tabular}

Table 4. Alignment of hpmB gene sequence Proteus mirabilis strain T18

\begin{tabular}{lccll}
\hline \multicolumn{2}{l}{$\begin{array}{l}\text { Sequence ID: CP017085.1Length: } 4131426 \\
\text { Score }\end{array}$} & Range 1: 3196590 to 3196919 & \\
610 bits(330) & $8 \mathrm{e}-171$ & Identities & Gaps & Strand \\
& & $330 / 330(100 \%)$ & $0 / 330(0 \%)$ & Plus/Plus \\
\hline
\end{tabular}

Query 1 GAAATTAATCAATTAATAGAACAAAATCGCTATCAGCAACTGCAAGAAAAAGCGGTAAAT 60 Sbjct 3196590 GAAATTAATCAATTAATAGAACAAAATCGCTATCAGCAACTGCAAGAAAAAGCGGTAAAT 3196649 Query 61 ATTTCACCTACCCCAACTTTAATTACTGAGTCAGAACACTGTTTGCCTATAAAAGGCGTT 120 Sbjct 3196650 ATTTCACCTACCCCAACTTTAATTACTGAGTCAGAACACTGTTTGCCTATAAAAGGCGTT 3196709 Query 121 TATATTCAAGGTATTACTTTACTTACTGAGAAGGATCTCAATTCATTATCTCCGTTACCT 180 Sbjct 3196710 TATATTCAAGGTATTACTTTACTTACTGAGAAGGATCTCAATTCATTATCTCCGTTACCT 3196769 Query 181 GATCAATGTATTAAGAGTGCTGATATTAATCGCCTCGTGAAAGAACTCACTCAGCGTTAT 240 Sbjct 3196770 GATCAATGTATTAAGAGTGCTGATATTAATCGCCTCGTGAAAGAACTCACTCAGCGTTAT 3196829 Query 241 CTTCAACATGGTTATATTACCGCGCGTATCCAATTTTTACGTCCTAACCAACATGGCGAA 300 Sbjct 3196830 CTTCAACATGGTTATATTACCGCGCGTATCCAATTTTTACGTCCTAACCAACATGGCGAA 3196889 Query 301 TTAGGTCTGTATGCTATTGAAGGGTTTGTT 330 Sbjct 3196890 TTAGGTCTGTATGCTATTGAAGGGTTTGTT 3196919

Table 5. Alignment of $h p m B$ gene sequence Proteus mirabilis strain AR_0059

\begin{tabular}{|c|c|c|c|c|}
\hline \multicolumn{5}{|c|}{ Sequence ID: CP020052.1Length: 4191021 Range 1: 2389008 to 2389362} \\
\hline Score & Expect & Identities & Gaps & Strand \\
\hline 645 bits(349) & 0.0 & $353 / 355(99 \%)$ & $0 / 355(0 \%)$ & Plus/Minus \\
\hline Query 1 & \\
\hline Sbjct 3196590 & \multicolumn{4}{|c|}{$\begin{array}{l}\text { GAAATTAATCAATTAATAGAACAAAATCGCTATCAGCAACTGCAAGAAAAAGCGGTAAAT } 60 \\
0 \text { GAAATTAATCAATTAATAGAACAAAATCGCTATCAGCAACTGCAAGAAAAAGCGGTAAAT } 3196649\end{array}$} \\
\hline Query 61 & \\
\hline Sbjct 3196650 & \multicolumn{4}{|c|}{$\begin{array}{l}\text { ATTTCACCTACCCCAACTTTAATTACTGAGTCAGAACACTGTTTGCCTATAAAAGGCGTT } 120 \\
0 \text { ATTTCACCTACCCCAACTTTAATTACTGAGTCAGAACACTGTTTGCCTATAAAAGGCGTT } 3196709\end{array}$} \\
\hline Query 121 & \multicolumn{4}{|c|}{ TATATTCAAGGTATTACTTTACTTACTGAGAAGGATCTCAATTCATTATCTCCGTTACCT 180} \\
\hline Sbjct 3196710 & \multicolumn{4}{|c|}{0 TATATTCAAGGTATTACTTTACTTACTGAGAAGGATCTCAATTCATTATCTCCGTTACCT 3196769} \\
\hline Query 181 & \multicolumn{4}{|c|}{ GATCAATGTATTAAGAGTGCTGATATTAATCGCCTCGTGAAAGAACTCACTCAGCGTTAT 240} \\
\hline Sbjct 3196770 & \multicolumn{4}{|c|}{0 GATCAATGTATTAAGAGTGCTGATATTAATCGCCTCGTGAAAGAACTCACTCAGCGTTAT 3196829} \\
\hline Query 241 & \\
\hline Sbjct 3196830 & \multicolumn{4}{|c|}{$\begin{array}{l}\text { CTTCAACATGGTTATATTACCGCGCGTATCCAATTTTTACGTCCTAACCAACATGGCGAA } 300 \\
0 \text { CTTCAACATGGTTATATTACCGCGCGTATCCAATTTTTACGTCCTAACCAACATGGCGAA } 3196889\end{array}$} \\
\hline Query 301 & \\
\hline Sbjct 3196890 & \multicolumn{4}{|c|}{$\begin{array}{l}\text { TTAGGTCTGTATGCTATTGAAGGGTTTGTT } 330 \\
0 \text { TTAGGTCTGTATGCTATTGAAGGGTTTGTT } 3196919\end{array}$} \\
\hline
\end{tabular}


Table 6. Alignment of hemolysin activation protein [Proteus mirabilis]

Sequence ID: WP_074561482.1 Length: 561 Identical proteins to WP_074561482.1

\begin{tabular}{lllllll} 
Score & Expect & Method & Identities & Positives & Gaps & Frame \\
228 & $2 \mathrm{e}-70$ & Compositional & $110 / 110$ & $110 / 110$ & $0 / 110$ & +1 \\
bits(582) & & matrix adjust. & $(100 \%)$ & $(100 \%)$ & $(0 \%)$ & \\
\hline
\end{tabular}

$\begin{array}{ll}\text { Query } 1 & \text { EINQLIEQNRYQQLQEKAVNISPTPTLITESEHCLPIKGVYIQGITLLTEKDLNSLSPLP } \\ \text { 180Sbjct 43 } & \text { EINQLIEQNRYQQLQEKAVNISPTPTLITESEHCLPIKGVYIQGITLLTEKDLNSLSPLP } \\ \text { 102Query 181 } & \text { DQCIKSADINRLVKELTQRYLQHGYITARIQFLRPNQHGELGLYIEGFV } \\ \text { 330Sbjct 103 } & \text { DQCIKSADINRLVKELTQRYLQHGYITARIQFLRPNQHGELGLYAIEGFV } 152\end{array}$

Table 7. Alignment of hemolysin activation protein [Proteus mirabilis]

\begin{tabular}{|c|c|c|c|c|c|c|}
\hline Score & Expect & Method & Identities & Positives & Gaps & Frame \\
\hline $\begin{array}{l}244 \\
\text { bits(623) }\end{array}$ & $2 e-76$ & $\begin{array}{l}\text { Compositional } \\
\text { matrix adjust. }\end{array}$ & $\begin{array}{l}118 / 118 \\
(100 \%)\end{array}$ & $\begin{array}{l}118 / 118 \\
(100 \%)\end{array}$ & $\begin{array}{l}0 / 118 \\
(0 \%)\end{array}$ & +1 \\
\hline
\end{tabular}

Query 2 RALQDSQREINQLIEQNRYQQLQEKAVNISPTPTLITESEHCLPIKGVYIQGITLLTEKD 181 Sbjct 35 RALQDSQREINQLIEQNRYQQLQEKAVNISPTPTLITESEHCLPIKGVYIQGITLLTEKD 94 Query 182 LNSLSPLPDQCIKSADINRLVKELTQRYLQHGYITARIQFLRPNQHGELGLYAIEGFV 355 Sbjct 95 LNSLSPLPDQCIKSADINRLVKELTQRYLQHGYITARIQFLRPNQHGELGLYAIEGFV 152

Therefore, the study finds a great importance in the genetic sequence of $P$. mirabilis virulence factors. The study finds that variant isolates possess polymorphism in hpmB genes.

\section{A phylogenic tree based on the hpmB gene}

Molecular phylogenetic is a branch of phylogeny that analyzes hereditary molecular differences mainly in DNA sequences to gain information on an organisms' evolutionary relationships ${ }^{20}$. The identified genetic profile of any bacteria by a specific genotyping method can be as unique as fingerprint ${ }^{20}$.

However, phylogeny estimated from a single gene should be treated with caution ${ }^{21,22}$. The phylogenetic tree derived from hpmB gene sequences of clinical strains of 2 samples Proteus

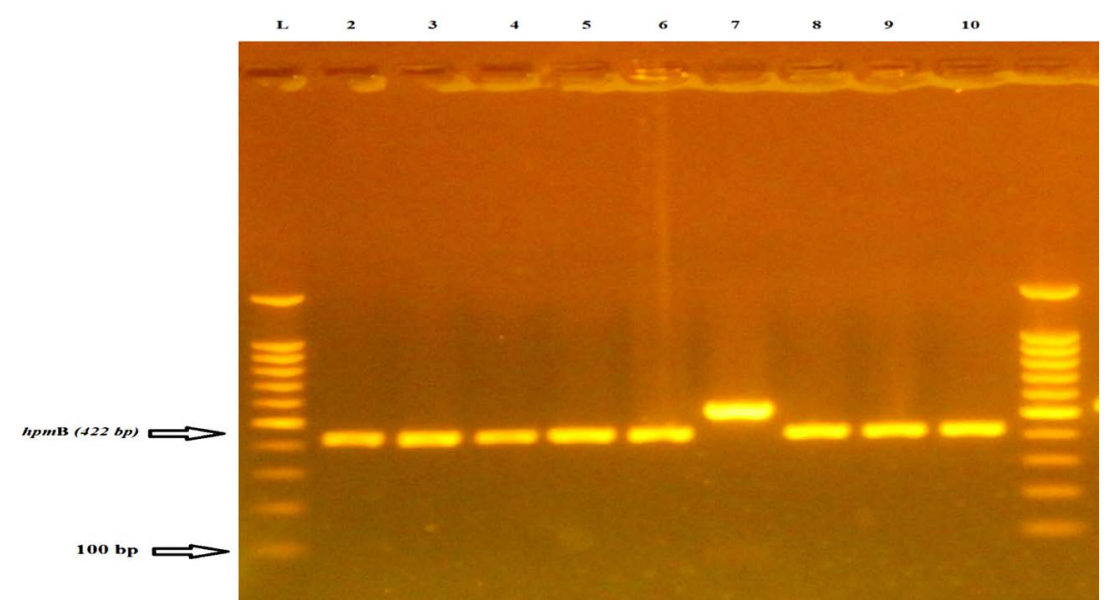

Fig. 1. Agarose gel electrophoresis ( $2 \%$ agarose, $75 \mathrm{~V}$ for $1: 45$ hour) of hpmB and PCR products (422bp) codify for $\alpha$-hemolysin of P. mirabilis isolates. Lane 1DNA ladder), 100-1100bp molecular marker, lanes $2,3,4,5,6,7,8,9,10$ isolates were positive results. 
mirabilis with other sequences is available at $\mathrm{NCBI}$ showed in (Fig.2). As to be seen in the this figure, $P$. mirabilis (MF993443) lies in the same branch of the phylogenetic tree with P.mirabilis (WP_088207120.1).

Sequences of 16SrRNA with the size of $1.5 \mathrm{~Kb}$ is considered and widely used in bacterial taxonomy because it contains high conservation region which has variable region in different species. Furthermore, the most important was that 16SrRNA gene which could be sequenced easily ${ }^{22}$. On the other hand, the sensitivity of this approach is questioned particularly among human bacterial closely related to Enterobacteriaceae, which includes many common pathogens because of the high degree of conservation in species $^{22}$. Therefore, the use of other genes rather than16SrRNA gene and the distinction between bacteria at the species level is regarded as a very important issue ${ }^{23}$. Results indicate that since there is an increase in clinical significance of $P$. mirabilis, the choice of effectual molecular methods is of great epidemiological reputation. Bacterial genotyping opened new chances on epidemiological studies by the documentation of clinical and ecological isolates, the assessment of this association, the watching of clone propagation and the classification of bacterial populations within more or less constrained environments ${ }^{24}$. By joining molecular phylogeny with traditional approach such as morphological, physiological and biochemical characteristics, bacteria identification could be achieved in a more accurate way ${ }^{25,26}$.

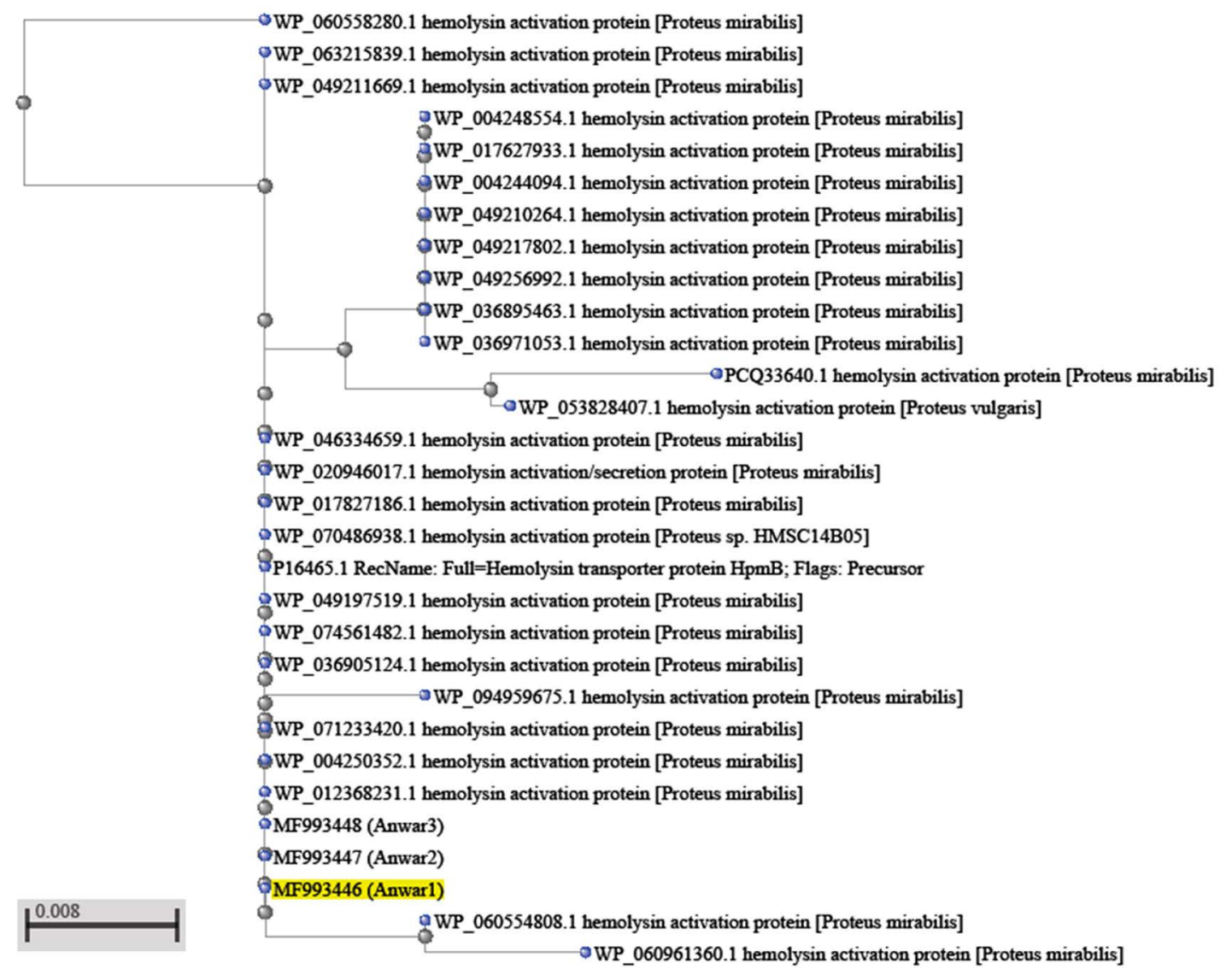

Fig. 2. Phylogenetic tree of Proteus species based on $h p m B$ gene sequence analysis. 


\section{ACKNOWLEDGMENT}

None

\section{CONFLICT OF INTERESTS}

The authors declare that there is no conflicts of interest.

\section{REFERENCES}

1. Shakibaie, M., Forootanfar, H., Golkari, Y., MohammadiKhorsand, T., and Shakibaie, M. R. Anti-biofilm activity of biogenic selenium nanoparticles and selenium dioxide against clinical isolates of Staphylococcus aureus, Pseudomonas aeruginosa, and Proteus mirabilis. J Trace Elem Med Biol. 2015; 29:235-241.

2. Mohammed, G. J., Kadhim, M. J., and Hameed, I. H. Proteus species: Characterization and herbal antibacterial: A review. International J Pharmacog and Phytochem Res, 2016; 8(11):1844-1854.

3. Stankowska, D., Kwinkowski, M., and Kaca, W. Quantification of Proteus mirabilis virulence factors and modulation by acylated homoserine lactones. J Microbiol Immunol Infect, 2008; 41(3):243-253.

4. Howery, K. E., Clemmer, K. M., and Rather, P. N. The Rcs regulon in Proteus mirabilis: implications for motility, biofilm formation, and virulence. Curr Genetics, 2016; 62(4):775-789.

5. Ouda, S. M. Some nanoparticles effects on Proteus sp. and Klebsiella sp. isolated from water. Am J Infect Dis Microbiol, 2014; 2(1):4-10.

6. Cestari ,S.E., Ludovico,M.S., Martins,F.H., Rocha,S.P.D., Elias,W.P. and Pelayo. J.S. Molecular Detection of HpmA and HlyA Hemolysin of Uropathogenic Proteus mirabilis. Curr Microbiol., 2013; 67:703-707.

7. Rozalski, A., Torzewska, A., Moryl, M., Kwil, I. Maszewska, A., Ostrowska, K., .and Stanzek, P. Proteus sp.-an opportunistic bacterial pathogen-classification, swarming growth, clinical significance and virulence factors. Folia Biologica et Oecologica, 2012; 8(1):1-17.

8. Uphoff, T. and Welch, R. Nucleotide sequencing of the Proteus mirabilis calcium independent hemolysin genes (hpmA and hpmB) reveals sequence similarity with Serratia marcescens hemolysin genes (shlA and shlB). J Bacteriol., 1990; 172:1206-1216.

9. Jumaily, E. F., and Zgaer, S. H. Characterization and molecular detection of purified Proteus mirabilis pmbs 41 alpha-hemolysin. Basrah J Veter Res, 2016; 15(3).

10. Liaw, S. J., Lai, H. C., Ho, S. W., Luh, K. T., and Wang, W. B. Role of RsmA in the regulation of swarming motility and virulence factor expression in Proteus mirabilis. $J$ Med Microbiol, 2003; 52(1):19-28

11. Swihart, K. G., and Welch, R. A. The HpmA hemolysin is more common than HlyA among Proteus isolates. Infect and Immun, 1990; 58(6):1853-1860.

12. Sosa, V.; Schlapp, G.and Zunino, P. Proteus mirabilis isolates of differentorigins do not show correlation with virulence attributes and can colonize the urinary tract of mice. Microbiol, 2006; 152(7):2149-2157.

13. AL-Jumaa, M. H.; Bnyan, I. A. and Al-Khafaji, J. K.
Bacteriological and Molecular Study of Some Isolates of Proteus mirabilis and Proteus vulgaris in Hilla Province. A thesis for the Degree of Master of Science in Microbiology. College of Medicine, University of Babylon, 2011.

14. Mishara, M.; Thakar, Y.S. and Pathak, A.A. Haemagglutination, haemolysin production and serum resistance of Proteus and related species isolated from clinical sources, Indian J Med Microbiol. 2001; 19(2):511

15. Abdul-Lateef, L. A. Sequencing of Proteus Toxic Agglutinin (Pta) Gene in Proteus Mirablis and Cytotoxic Effect of Pta on Human Colon Cancer Cell and Human Kidney Cell. J Global Pharma Technol, 2017; 9(9).

16. Mordi, R. M., and Momoh, M. I. Incidence of Proteus species in wound infections and their sensitivity pattern in the University of Benin Teaching Hospital. African J Biotechnol, 2009; 8(5).

17. Fraser GM, Claret L, Furness R, Gupta S, Hughes C. Swarming-coupled expression of the Proteus mirabilis hpmBA haemolysin operon. Microbiol, 2002; 148:2191-2201.

18. Strauss, E. J., Ghori, N., and Falkow, S. An Edwardsiella tarda strain containing a mutation in a gene with homology to shIB and hpmB is defective for entry into epithelial cells in culture. Infect and Immun, 1997; 65(9):3924-3932.

19. Plomin, R., DeFries, J. C., Knopik, V. S., and Neiderheiser, J. Behavioral genetics. Palgrave Macmillan, 2013.

20. Li, W., Raoult, D., and Fournier, P. E. Bacterial strain typing in the genomic era. FEMS Microbiol Revs, 2009; 33(5):892-916.

21. Hadfield, J. D., and Nakagawa, S. General quantitative genetic methods for comparative biology: phylogenies, taxonomies and multi trait models for continuous and categorical characters. J Evolution Biol, 2010; 23(3), 494-508.

22. Case, R. J., Boucher, Y., Dahllof, I., Holmstrym, C., Doolittle, W. F., and Kjelleberg, S. Use of $16 \mathrm{~S}$ rRNA and $r p o B$ genes as molecular markers for microbial ecology studies. Appl Environmen Microbiol, 2007; 73(1):278-288.

23. Ghebremedhin, B., Layer, F., Konig, W., and Konig, B. Genetic classification and distinguishing of Staphylococcus species based on different partial gap, 16S rRNA, hsp60, rpoB, sodA, and tuf gene sequences. J Clinic Microbiol, 2008; 46(3):1019-1025.

24. Michelim, L., Muller, G., Zacaria, J., Delamare, A. P. L., Costa, S. O. P. D., and Echeverrigaray, S. Comparison of PCR-based molecular markers for the characterization of Proteus mirabilis clinical isolates. Brazilian J Infect Dis, 2008; 12(5), 423-429.

25. Ma, R., Wu, X., Wang, R., Wang, C., and Zhu, J. Identification and phylogenetic analysis of a bacterium isolated from the cloaca of Chinese alligator. African $\mathrm{J}$ Biotechnol, 2008; 7(13).

26. Brenner, D. J., Staley, J. T., and Krieg, N. R. Classification of Procaryotic Organisms and the Concept of Bacterial Speciation. Bergey's Manual of Systematics of Archaea and Bacteria, 2015; 1-9. 